\title{
BARRIERS AND DRIVERS TO ECO- INNOVATION: COMPARATIVE ANALYSIS OF GERMANY, POLAND AND UKRAINE
}

\author{
Ihor Hrabynskyi ${ }^{1, a}$, Nataliya Horin ${ }^{2, b, *}$ and Liliya Ukrayinets ${ }^{3, \mathrm{c}}$ \\ ${ }^{1}$ Ivan Franko National University of Lviv, 1 Universytetska Str., Lviv 79000, Ukraine \\ ${ }^{2}$ Ivan Franko National University of Lviv, 1 Universytetska Str., Lviv 79000, Ukraine \\ ${ }^{3}$ Ivan Franko National University of Lviv, 1 Universytetska Str., Lviv 79000, Ukraine \\ aihor.hrabynskyi@1nu.edu.ua, btalya_gorin@yahoo.com, lilia.ukrainets@gmail.com \\ *Corresponding author
}

\begin{abstract}
The paper attempts to investigate the driving and restricting forces of ecoinnovations. We determined the most important barriers to eco-innovation that can be classified mainly in three groups such as: external, internal, and international factors. The major barriers to the development of the firms' eco-innovative activity have been identified as the lack of funds within the enterprises, lack of external financing, uncertain demand at the market, uncertain return from investment, unhelpful regulations, lack of knowledge and experience. It is determined that in Ukraine the corruption of public officials has one the most restricting impacts on eco-innovative activities of enterprises. The study shows that eco-innovative activities of firms of all sizes are growing but large enterprises are the most eco-innovative ones. The Eco-innovation Index for Ukraine was calculated; it shows that Ukraine has the lowest position of eco-innovative efficiency in comparison with Germany and Poland. But despite the different levels of eco-innovativeness in Ukraine and the EU Members (using the example of Poland and Germany), the main barriers and drivers to eco-innovation are roughly the same in all of these countries. Based on the interview surveys we found that the most important drivers of eco-innovative activity in Ukraine are the following: existing environmental regulations and taxes, improvement of the company's reputation on the market, as well as the reduction in operating costs on energy, water and materials.
\end{abstract}

Keywords: eco-innovation activity, barriers to eco-innovation, external barriers, internal barriers, drivers to eco-innovation.

JEL Classification: O31, Q55, F640.

\section{Introduction}

Modern innovation policy is becoming more and more environmentally oriented while the development of world economy is characterized by the growth of the environmental pollution that has become a global problem for years ago. We can see the increasing role of the adoption of ecological innovations in all countries for environmental protection, sustainable development, the implementation of international treaties as well as for the provision of their international competitiveness. (Constantini et al., 2017, Bossie et al., 2016) Therefore, the implementation of sustainable development goals related with the environmental protection needs a fundamental change in economic activity (Open Working Group...). This is the priority for the leading international organization such as United Nations (UN) or the Organization for Economic Co-operation and Development (OECD). Also the European Union (EU) as the unique economic and political union between 28 European countries implements 
its own growth strategy - Europe 2020 - that stresses the importance of eco-innovation. Under the new EU framework known as the Innovation Union the EU implements a complex approach to this sphere via reforming the members' economic development towards the ecologization, implementing the members' national innovative development policies and creating the European Innovation Partnerships that promotes knowledge transfer for productivity and sustainability. (Triguero et al., 2013, Levidow, 2016, Ociepa-Kubicka \& Pachura, 2016). According to Kemp (Kemp, 2011), eco-innovation is a prime candidate for "new mission" policies to deal with (interrelated) societal challenges of climate change, resource efficiency, and energy/resource scarcity.

Defining eco-innovation is not an easy task although several attempts have been made in the literature (Rio et al., 2016). It should be noted that several terms have been used to describe eco-innovation: green innovation, sustainable innovation, eco-innovation and environmental innovation (Schiederig et al., 2012, Tsai \& Liao, 2017, Xavier et al., 2017). In general, these definitions emphasize that eco-innovation is an innovation distinguished by two characteristics (OECD, 2010):

1) eco-innovation represents an innovation that leads to the reduction of environmental impact, regardless of whether such an effect is purposed or not;

2) the scope of eco-innovation may go beyond the conventional organizational boundaries and involve the wider community that generates changes within existing socio-cultural norms and institutional structures.

Horbach et al. (Horbach et al., 2011) point on three important features of eco-innovation: it is based on a subjective view of innovation (i.e. the innovation has to be new for the firm), it only considers implemented innovations (rather than activities targeted at reducing environmental impacts), and it relates environmental impacts to the state of the art.

Now policy-makers are looking for the effective eco-innovation strategies with sciencebased strategic and operational goals and instruments (Pujari, 2006).

There are two kinds of trends of the eco-innovation policy involved, one to do with environmental pollution and the other with the innovation and diffusion of new technologies (Rennings, 2000; Jaffe et al., 2005). Therefore without a variety of the instruments especially designed under the effective eco-innovation policy, firms pollute too much and innovate too little compared with the social optimum (Haščič et al., 2009). In this case the share of innovative firms that do not 'ecoinnovate' in any form (intentionally or unintentionally) is only between 20\%-30\% (Kemp \& Person, 2007). Thus, as noted by Rennings and Jaffe et al. (Rennings, 2000; Jaffe et al., 2005), the environmental innovation policy has the dual effect upon increasing the innovation across all economic sectors and improving the state of the environment for the benefit of the citizens of the country as well as for the rest of the world.

Eco-innovation aims to create both economic and environmental values, and business implements innovations much more actively. (Hellstrom, 2017) The evidence-based literature review shows that economic aspects of the ecological innovations, such as the barriers and drivers to eco-innovation, the directions and instruments of eco-innovation policy, and its impact on firms' eco-innovative activity have not been thoroughly studied and analyzed. The available studies generally confirm the necessity of the theoretical and practical determinants of restriction and driving forces to eco-innovation. (Constantini et al., 2017) Thus in 2016 the most complete critical review of the world empirical literature on eco-innovation was carried out by Rio et al. (Rio et al., 2016). As the results authors found the following gaps in knowledge about eco-innovation: 
- an integrated theoretical framework which merges the insights from different approaches is missing;

- the influence of some variables is still unclear (demand-pull and cost-savings), whereas others have hardly been included in previous analyses (internal and international factors);

- studies on the drivers to eco-innovation versus general innovation are relatively scarce with respect to those on the drivers to ecoinnovation in general;

- studies on middle-income and developing countries are still scarce;

- detailed econometric analyses on the specific drivers and barriers to eco-innovation in different sectors and regions have not been performed so far.

Thus the study aims to contribute to the existing research on driving and restricting forces to eco-innovation, and to define the major barriers to eco-innovation in Germany and Poland as two the EU Member States respectively with one of the highest and one of the lowest position in the eco-innovativeness scoreboard, and in Ukraine as a country with low level of ecoinnovativeness.

\section{Data and Methodology}

Data used for the analyses are taken from the database of the State Statistics Service of Ukraine, the Eurostat and the World Bank official statistics, the Centre for European Economic Research in Germany. Information framework of paper is based on the EU members' and Ukrainian laws and regulations in eco-innovation policies, regulatory framework of the EU and OECD, scientific publications.

The empirical analysis of the literature has allowed us to find the most important barriers to eco-innovation and to group them by the direction of their origin.

The system and functional approaches were used as methodological base of the paper. The scientific methods and principles, such as scientific abstraction, the analysis and synthesis, comparison, induction and deduction were applied.

Based on the Eco-Innovation Scoreboard as the first tool to assess and illustrate ecoinnovation performance across the EU Members we have calculated the size of Eco-innovation Index for Ukraine. This index aims at capturing the different aspects of eco-innovation by applying 16 indicators grouped into five thematic areas: eco-innovation inputs, eco-innovation activities, eco-innovation outputs, resource efficiency and socio-economic outcomes. It has allowed us to show how well Ukraine performs in different dimensions of eco-innovation compared to the EU Members.

We used a structured interview as a method of data collection in quantitative research to reveal the main barriers and drivers to eco-innovation in the case of Ukraine.

Data received from the owners and top-managers of 254 Ukrainian enterprises were carefully aggregated and the comparisons with data collected by the EU research institutions were made. Ukrainian enterprises were selected using a stratified random sampling methodology. The dataset is a relatively large one totaling 254 enterprises covering roughly the same numbers of size classes - 82 small, 84 middle and 88 large-sized enterprises. 


\section{Results}

Previous researches (Bielikova \& Mazanec, 2016; Hojnik \& Ruzzier, 2016) show that the barriers of the development of the firms' eco-innovative activity may be divided into two groups:

- External barriers - are characterized by external environment;

- Internal barriers - based on the nature of the business entity.

The leading role among the external barriers belongs to following (Grandinetti, 2016; Skypalova et al., 2016; Bielikova \& Mazanec, 2016):

- limited access to financial resources and the high risk of eco-innovative projects. Therefore, the acquisition of commercial loans is difficult. Mostly the enterprises, especially small and medium-sized, have the ability to get a loan on less favorable terms;

- high tax burden;

- unclear legislation, which is complicated and changes regularly;

- administrative bureaucracy in the governmental institutions and in the companies;

- information and institutional barriers that represent underdeveloped information system.

Based on our own investigations we have determined that the corruption of public officials has one of the most restricting impacts on eco-innovativeness especially in the developing and transition economies. It may place a major administrative and financial burden on firms and creates unfavorable conditions for eco-innovative activity of firms by undermining the operational efficiency and raising the costs and risks associated with implementation of ecoinnovative projects. In many countries bribes are common and quite high and they add to the bureaucratic costs of obtaining required permits and licenses. For example, in Ukraine the Graft Index - the index of corruption measured by the World Bank and reflecting the share of times when a firm was asked or expected to pay a bribe - was estimated as $40,4 \%$ (Ukraine, 2013). It means that the costs of eco-innovative projects will rise on $40 \%$ in average.

According to Almodovar et al. (Almodovar et al., 2016) the internal barriers of ecoinnovative activity are the following:

- lack of motivation - the motivation level may rise or decrease depending on firms' opportunities to realize their own profit, ideas, and so on;

- lack of capital - as usual the enterprises do not have free cost to fund the eco-innovative projects, which are long-term and expensive;

- lack of knowledge and experience - cause that firms are not be able to compete against their competitors who act on the market and have some experience and expertise. Access to technological knowledge may thus pose a particularly important barrier for green firms (Jakobsen \& Clausen, 2014).

A recent review study by Hojnik and Ruzzier (Hojnik \& Ruzzier, 2016) has concluded that among the internal drivers, the central focus has been placed on environmental concerns and cost reduction, while the most important external drivers are customer pressure, competition and regulatory pressure. Costs (upfront investment for eco-innovation implementation) prevail within the internal barriers, while legislation seems to be the most commonly experienced external barrier.

Other authors (Rio et al., 2016) indicate that there is an additional set of barriers that can be defined as the international factors group, which may include the following:

- influence of customers in foreign markets; 
- international regulations;

- international sources of funding;

- cooperation with international institutions;

- presence of foreign equity in firms.

The OECD experts have identified three groups of restrictions according to their influence on the firms' eco-innovative activity (OECD, 2005):

- barriers that prevent firms from starting innovative activities;

- barriers that slow innovation activity;

- barriers that have a negative effect on expected results.

Based on prior researches and theories on eco-innovative development we assume that the most important question should be the search of the ways and directions for avoiding the restrictiveness and minimizing the negative impacts of different groups of barriers on ecoinnovative activity. The reason is that such barriers hinder the natural flow of innovation and may hinder the structural change towards increased sustainability. According to Jakobsen and Clausen (Jakobsen \& Clausen, 2014) once the barriers to innovation are identified and their effect is understood, action might be taken to eliminate them justifying why it is relevant to explore what barriers to innovation environmental firms face and the extent to which these barriers are stronger within environment firms.

In 2011 Eurobarometer has made a large expert survey of 5,222 of enterprises in the EU-27 member countries. The owners and top-managers defined the most important barriers that constrain firms' ability to eco-innovate. According to the result, uncertain demand from the market and uncertain return are the two biggest obstacles to eco-innovation, followed by lack of funds and unhelpful regulations (see Fig. 1).

Figure 1. Barriers to accelerated eco-innovation uptake and development of firms in EU-27, \%

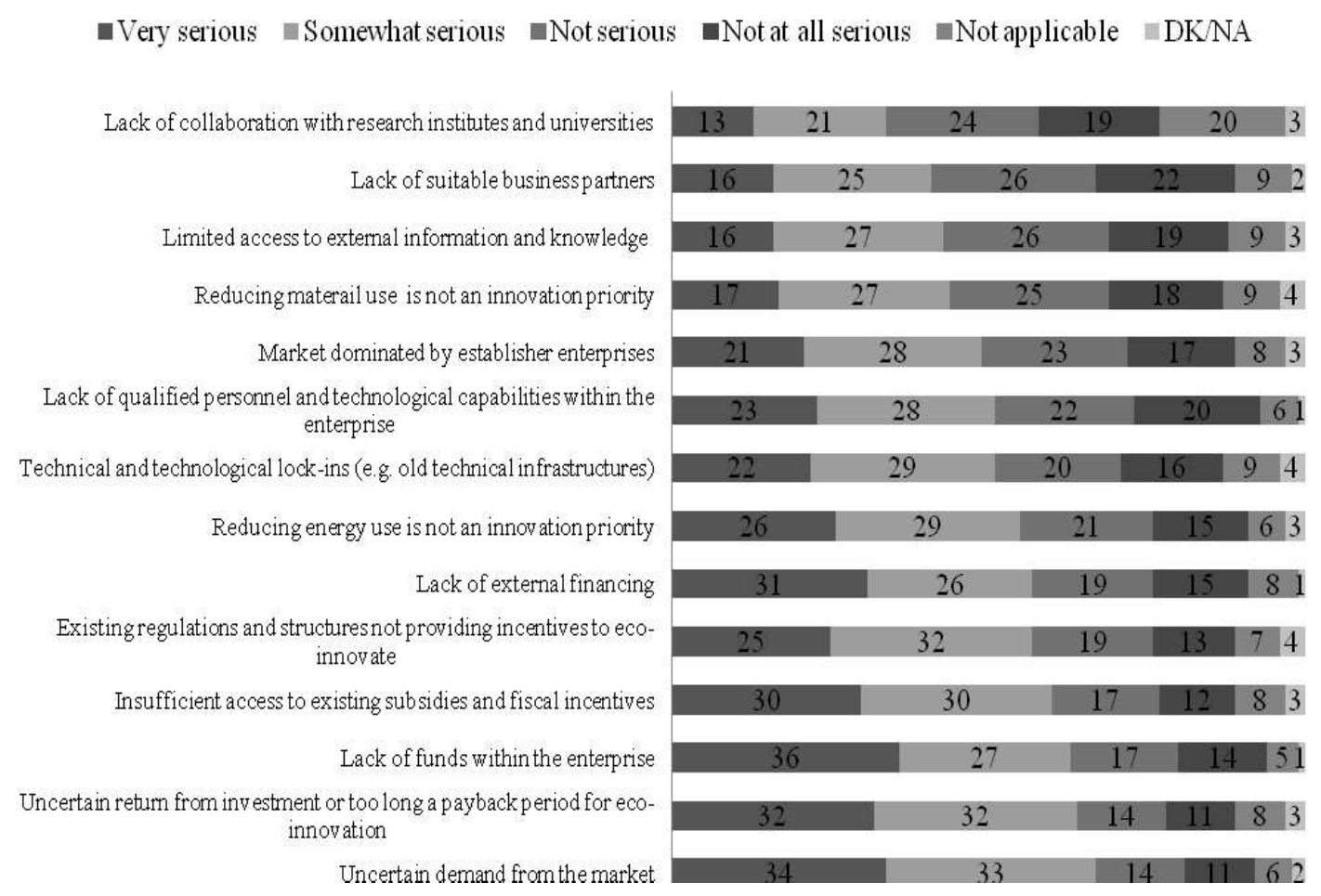

Source: Kemp, 2011. 
It has to be noted that all EU Members generally meet the same barriers to eco-innovation and policy-makers are obliged to pay great attention on existing restrictions to use correct and effective methods and instruments of eco-innovation policy. The study found the similarities and differences between the barriers and drivers to eco-innovation in individual countries for a sample for enterprises in Poland, Germany and Ukraine. We chose these countries due to the following reasons. Ukraine declared its European integration vector as priority, and the experience of Poland and Germany is especially valuable as these two countries, firstly, have a big territory with the diversity of ecosystems, though the eco-innovation and environmental efficiency are the main objectives of their sustainable development; secondly, today in these countries the eco-innovative activity is one of the fastest growing field, thirdly, in the frame of the EU growth strategy and the European Innovation Partnership Poland and Germany receive the most funds, a significant portion of which is aimed at the eco-innovative development of their economies; finally, Germany represents an "old " member state of the UE, while Poland is a "new" one which deals with the EU rules and regulations relatively recently.

The research of Polish eco-innovative development has shown that Poland is the country with low level of eco-innovative efficiency (see Fig. 2) and need more effective state supporting program of eco-innovation and sustainable development.

Figure 2. Eco-innovation Index for EU-28 and Ukraine, 2015

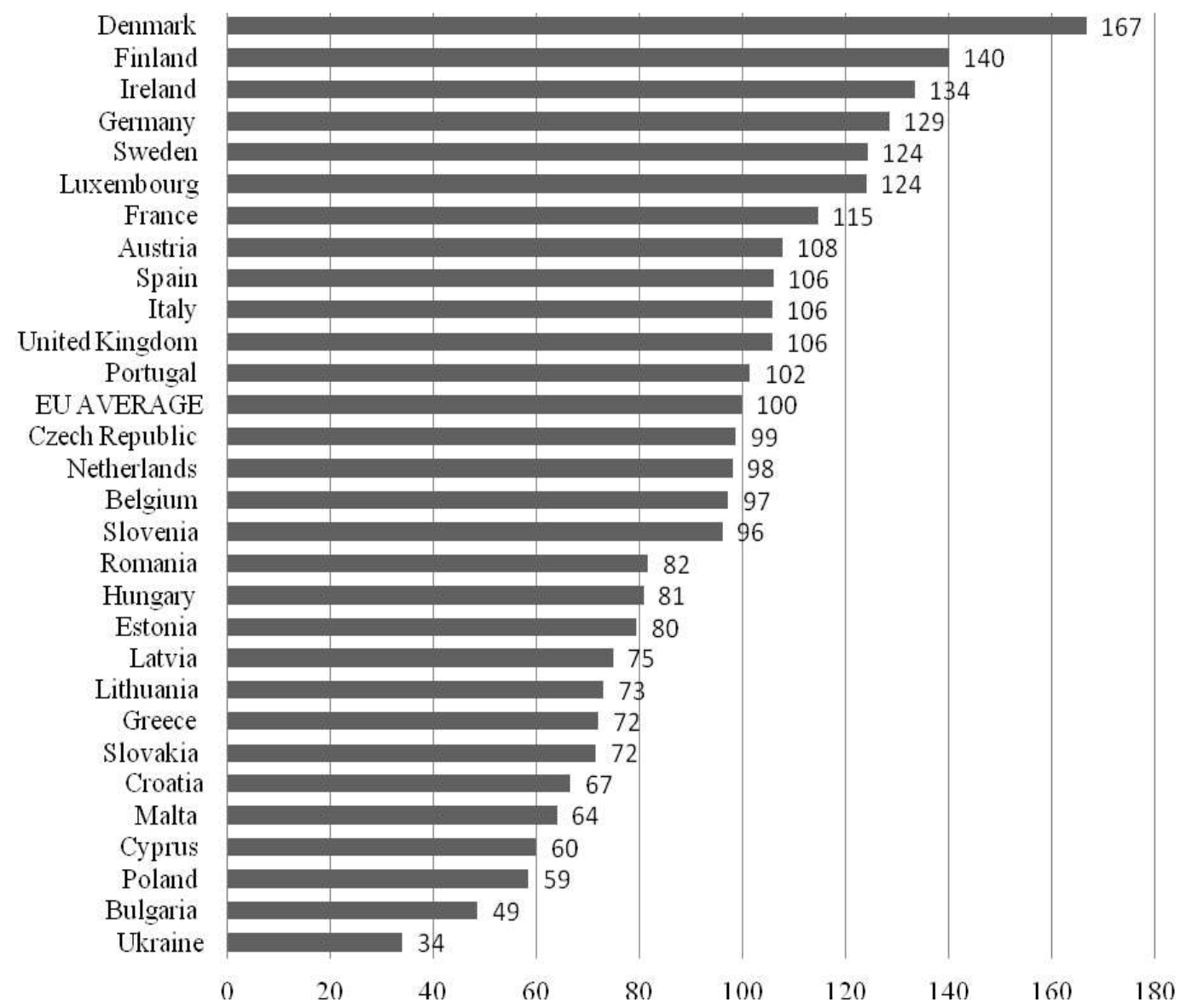

Source: Own compilation based on own calculation (in case of Ukraine) and on (The Eco-Innovation Scoreboard ...) (in case of the EU) 
The drivers and barriers to eco-innovation in Poland were thoroughly studied by Urbaniec (Urbaniec, 2015) and the overall list of internal and external factors that support or inhibit the development of eco-innovation in this country is presented in Tab. 1.

Table 1. Drivers and barriers for eco-innovation in Poland

Drivers Barriers

- A large number of strategic documents refer to the significant role of eco-innovations in Poland's development

- Establishment of numerous local initiatives that can involve into eco-innovation promotion

- Slow but steady consolidation of the scientific and technological base

- New requirements of the increasingly stringent environmental protection law

- The new EU financial perspective for 2014-2020, with a focus on innovativeness, lowcarbon economy and sustainable development

Source: (Urbaniec, 2015)

In general five drivers of eco-innovation are defined in literature (Rennings \& Zwick 2003): regulation, demand from users, capturing new markets, cost reduction and firm's reputation. We use this classification to estimate and compare the importance of each of these drivers for German and Ukrainian business' eco-innovation activity.

According to the Eco-Innovation Scoreboard Germany is a country with high level of ecoinnovativeness and is ranked $4^{\text {th }}$ in the Eco-innovation Index (see Fig. 2).

The importance of studying of German experience in supporting and promotion of eco-innovation responds to Germany's leading position in the creation and adoption of eco-innovations. In Ukraine the state support of eco-innovative development is just starting, while in German it is developing dynamically. The main engine forces to eco-innovation in Germany are high cost of energy, water, and materials, existing environmental regulations and voluntary actions or initiatives for environmental good practice (see Tab. 2).

Table 2. Drivers of firms ' eco-innovation activity in Germany in 2012-2014, \% of total number of enterprises with eco-innovation

\begin{tabular}{|c|c|c|c|c|c|c|c|}
\hline 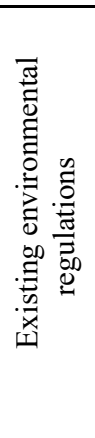 & 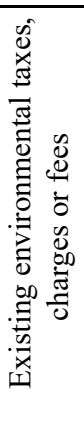 & 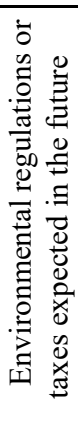 & 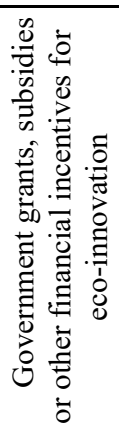 & 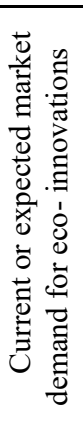 & 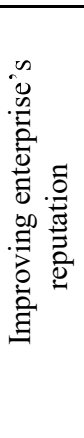 & 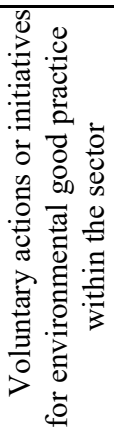 & 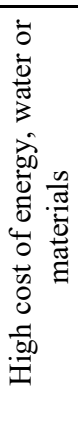 \\
\hline 15,8 & 4,4 & 7,3 & 5,0 & 3,8 & 9,3 & 11,4 & 24,4 \\
\hline 23,6 & 8,2 & 12,3 & 7,1 & 3,6 & 12,0 & 11,5 & 28,1 \\
\hline 37,0 & 12,9 & 17,9 & 5,9 & 11,8 & 19,5 & 16,4 & 34,3 \\
\hline 19,7 & 6,2 & 9,6 & 5,9 & 11,8 & 19,5 & 16,1 & 34,3 \\
\hline
\end{tabular}

Source: Own compilation based on the data of the Centre for European Economic Research (Environmental Performance...)

For Ukraine the importance of study is indicated by the reforming of economy and new program of innovative development that includes eco-innovation activity as well. But according 
to the research Ukraine is a country with very low eco-innovativeness and can be classified as the non-innovative either non-ecoinnovative country in Europe. As Fig. 2 shows Ukraine had reached a result significantly below of the EU-28 countries, occupying the last place in the Ecoinnovation Index score. It should be noted that Ukraine began to solve its ecological problems as far back as at the end of the 90s of the previous century. However, the EU countries had to deal with them much earlier. According to Environmental Performance Index - EPI (Environmental Performance), in 2016 Ukraine was ranked $44^{\text {th }}$ out of 180 countries. It should be noted that during the last two years its position has significantly improved - from the $95^{\text {th }}$ position in 2014. The low places in different rankings of eco-innovativeness are due to poor results in research and development as well as investments in environmental technologies. In 2015 eco-innovative activity of enterprises was funded almost from its own sources (85\%), $0,7 \%$ - from state and local budgets, $0.8 \%$ - by loans, and $1.3 \%$ - by domestic and foreign investment (Scientific and Innovation, 2016). Our analysis shows that eco-innovative activities of firms of all sizes are growing but the large enterprises are the most eco-innovative. Based both on the data of the State Statistics Service of Ukraine and on the collected data from direct interviews with a questionnaire, carried out with the owners and top-managers of Ukrainian enterprises (including 82 small, 84 middle and 88 large-sized firms), we found that the most important drivers of eco-innovative activity are the follows (see Tab. 3): existing environmental regulations and taxes, improvement of the company's reputation on the market, as well as the reduction in operating costs on energy, water and materials.

Table 3. Drivers of firms ' eco-innovation activity in Ukraine, \% of total number of enterprises with eco-innovation
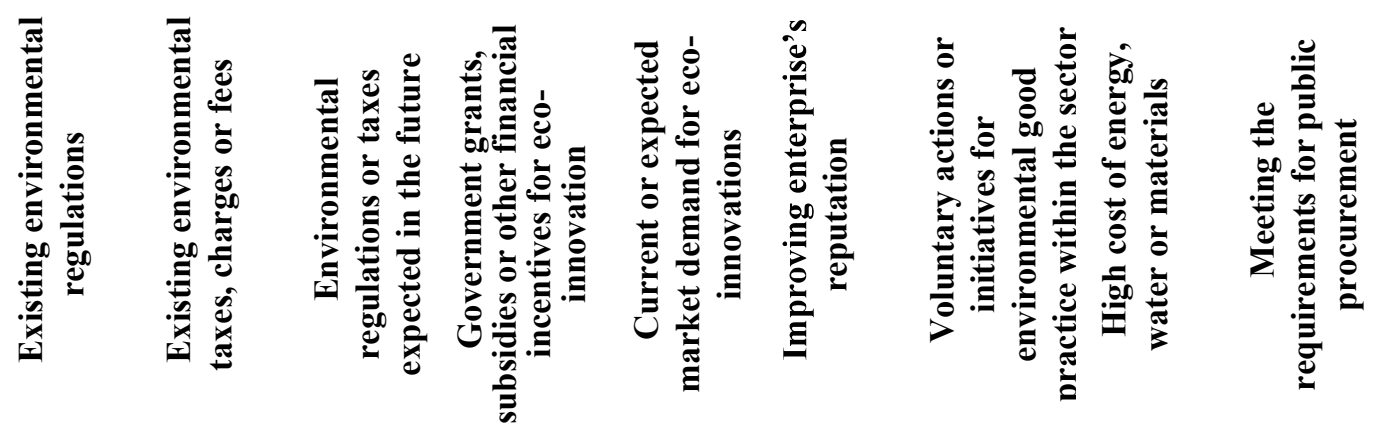

\begin{tabular}{llllllllll}
\hline \multicolumn{8}{c}{ According to the data of the State Statistics Service of Ukraine } \\
\hline Total & 11,9 & 7,2 & 6,5 & 1,3 & 3,7 & 8,1 & 6,2 & 15,8 & 3,7 \\
Small & 10,1 & 6,1 & 5,3 & 1,3 & 4,3 & 6,7 & 5,3 & 12,6 & 3,8 \\
Middle & 10,3 & 5,5 & 5,5 & 0,9 & 3,0 & 6,9 & 5,7 & 13,9 & 2,3 \\
Large & 18,7 & 12,7 & 11,0 & 2,0 & 3,3 & 13,4 & 9,2 & 26,4 & 5,7 \\
\hline \multicolumn{7}{c}{ According to the interview analysis } \\
\hline Total & 12,4 & 9,5 & 5,5 & 1,7 & 2,4 & 3,4 & 4,5 & 9,7 & 7,8 \\
Small & 3,5 & 3,5 & 1,8 & 0,0 & 0,0 & 0,0 & 0,0 & 3,5 & 1,8 \\
Middle & 8,8 & 8,8 & 3,5 & 0,0 & 1,7 & 1,7 & 1,7 & 8,8 & 1,7 \\
Large & 21,1 & 19,3 & 8,7 & 1,7 & 1,7 & 10,5 & 7,0 & 21,1 & 10,5 \\
\hline Source: Own elaboration based on structured interview analysis and own compilation based on the data of the \\
State Statistics Service of Ukraine (Scientific and Innovation.., 2016)
\end{tabular}

Despite the different levels of eco-innovativeness between the Germany and Ukraine the main barriers and drivers to eco-innovation are roughly the same in these countries (see Fig. 3). It allows suggesting that German experience in the field of eco-innovative development is highly essential and valuable for the Ukrainian science and practice. 
Figure 3: Comparison of drivers to eco-innovation activity in Ukraine and Germany

High cost of energy, water or materials

Voluntary actions or initiatives for environmental good practice within the sector

Improving enterprise's reputation

Current or expected market demand for ecoinnovations

Government grants, subsidies or other financial incentives for eco-innovations

Environmental regulations or taxes expected in the future

Existing environmental taxes, charges or fees

Existing environmental regulations

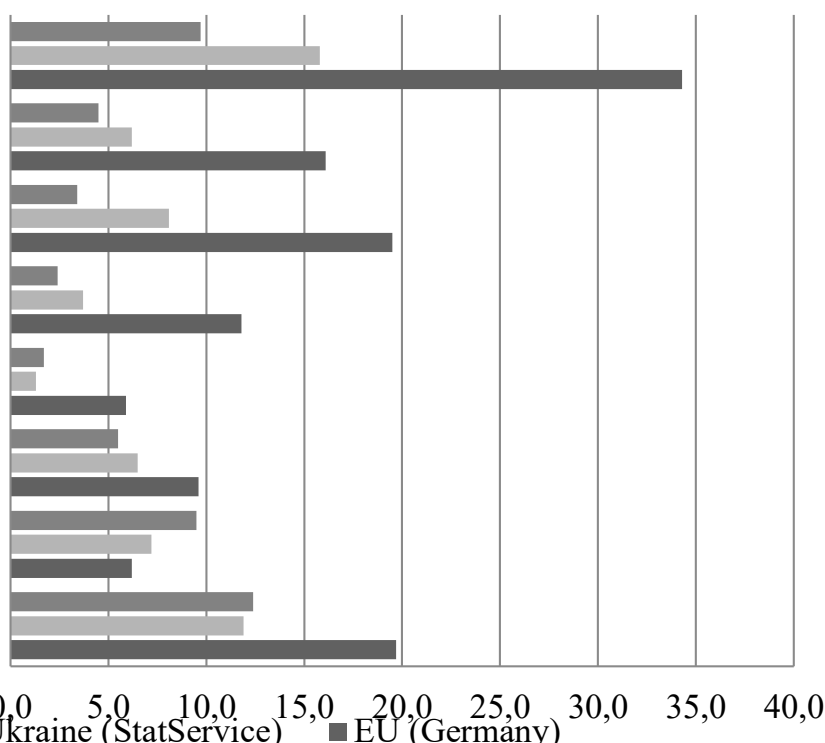

- Ukraine (Interview Survey)

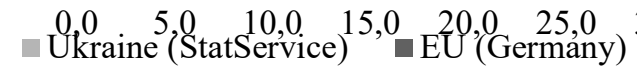

Source: Own elaboration based on structured interview analysis, data of the State Statistics Service of Ukraine and data of the Centre for European Economic Research.

It should be emphasized that there is a great eco-innovation potential in Ukraine, especially in raw materials savings industries. In spite of overall changes trends point to significant economic opportunities in the modernization of production processes, particularly in the most energy- and resource-intensive sectors.

\section{Discussion}

The problem of definition and evaluation of the forces which have the positive and negative effects on eco-innovation activity of enterprises is very important not only for individual firms, but also for industry organizations, universities, R\&D-institutes and the governments. Although more and more scientists, politicians, firms and customers focus on environmental issues, environmental regulations seems to be one of the main tool to change the market demand and the direction of business in the short run. It is particularly useful to find and adopt highly effective measures and instruments of eco-innovation policy. The future discussion and research work should be directed to the creation of scientifically justified eco-innovation strategy. The policy-makers must understand the economic and environmental benefits of the eco-innovation development, and enacts the policy measures and instruments to implement and stimulate the eco-innovative activity of the enterprises. In this case the analysis of the barriers and drivers to eco-innovation will be especially valuable for it.

The primary goal of further research may be to cover questions that are relevant to developing government policies encouraging firms to perform eco-innovation and also to inform about possible problems and advantages, such as impact on competitiveness, especially on international markets. It is also useful to obtain results for a specific policy measures for example whether or not the eco-innovation was introduced in response to a specific policy in different countries. 


\section{Conclusion}

The results of the study permit to do some conclusions. Eco-innovation activity is essential to respond to major current and future challenges of modern world society. Despite of its considerable importance the eco-innovation does not diffuse easily and quickly in any economy. Many factors (barriers and/or absence of drivers) contribute to this. For any country the identification of the barriers and drivers to eco-innovation is necessary for determination of instruments used under the framework of the eco-innovation policy and for catalyzing of sustainable development.

The implementation of eco-innovation depends on the different groups of factors that can be classified as external, internal and international.

The major barriers to eco-innovation have been identified as the lack of funds within the enterprises and the lack external financing, uncertain demand from the market, uncertain return from investment, unhelpful regulations, lack of knowledge and experience. It should be added that the corruption of public officials has very restricting impact on eco-innovative activities of enterprises. Especially it concerns the developing and transition economies where the bribes are common and quite high and they add to the bureaucratic costs in obtaining required permits and licenses. In general the enterprises from the countries with high level of index of corruption need more funds to spend on eco-innovation.

The comparative analysis of three countries - Germany, Poland and Ukraine - has determined that there are no differences in the barriers and drivers to firms' eco-innovation activity in any of these countries. But in Ukraine the corruption of public officials has one the most restricting impacts on eco-innovative activities of enterprises.

As for Ukraine the most important drivers of eco-innovation activity are: existing environmental regulations and taxes, improvement of the company's reputation on the market, as well as the reduction in operating costs on energy, water and material. The research shows that eco-innovative activities of firms of all sizes are growing but large enterprises are the most eco-innovative. Based on motives and barriers it can be concluded that the Ukrainian ecoinnovation market is at its initial stage of development.

\section{References}

[1] Almodovar, P., Verbeke, A., \& Rodrigues-Ruiz, O. (2016). Internationalization of small and medium-sized family enterprises: The role of human asset quality, Journal of Leadership and Organizational Studies, vol. 23, no. 2, pp. 162-174. doi: $10.1177 / 1548051816633066$

[2] Bielikova, A., \& Mazanec J. (2016). Small and Medium-sized Enterprises in the Global Economy. International Journal of Scientific and Engineering Research, vol. 7, no. 10, pp. 364-367.

[3] Bossie, M.B. et al (2016). The Drivers for Adoption of Eco-innovation. Journal of Cleaner production, vol. 113, pp. 861-872. doi: 10.1016/j.jclepro.2015.11.033

[4] Constantini, V., Crespi, F., Marin, G., \& Paglialunga, E. (2017). Eco-innovation, sustainable supply chains and environmental performance in European industries. Journal of cleaner production, vol. 155, no. 2, pp. 141-154. doi: 10.1016/j.jclepro.2016.09.038 
[5] Constantini, V., Crespi, F., \& Palma, A. (2017). Characterizing the policy mix and its impact on eco-innovation: A patent analysis of energy-efficient technologies. Research Policy, vol. 45, no. 4, pp. 799-819. doi: 10.1016/j.respol.2017.02.004

[6] Environmental Performance Index. [Online]. Available: http://epi.yale.edu/data

[7] Grandinetti, R. (2016). Absorptive capacity and knowledge management in small and medium enterprises, Knowledge Management Research and Practice, vol. 14, no. 2, pp. 159-168. doi: $10.1057 / \mathrm{kmrp} .2016 .2$

[8] Haščič, I., Johnstone, N., \& Kalamova, M. (2009). Environmental Policy Flexibility, Search and Innovation. Czech Journal of Economics and Finance, vol. 5, pp. 426-441.

[9] Hellstrom, T. (2017). Dimensions of environmentally sustainable innovation: the structure of eco-innovation concepts. Sustainable development, vol. 15, no. 3, pp. 148159. doi: $10.1002 / \mathrm{sd} .309$

[10] Hojnik, J., \& Ruzzier, M. (2016). Drivers of and barriers to eco-innovation: a case study. International Journal of Sustainable Economy, vol. 8, no. 4, pp. 152-164. doi: 10.1504/IJSE.2016.079433

[11] Horbach, J., Rammer, C., \& Rennings, K. (2011). Determinants of eco-innovations by type of environmental impact - The role of regulatory push/pull, technology push and market pull. Ecological Economics, vol. 78, pp. 112-122.

[12] Jaffe, A.B., Newell, R.G., \& Stavins, R.N. (2005). A tale of two market failures: Technology and environment policy. Ecological Economics, vol. 54, pp.164-174. doi: 10.1016/j.ecolecon.2004.12.027

[13] Jakobsen, S., \& Clausen, T. (2014). Comparing the innovation process in environmental and non-environmental firms: A look at barriers to innovation. DRUID Society Conference 2014, CBS, Copenhagen, 26 p.

[14] Kemp, R., \& Person, P. (2007). Final report MEI project about measuring ecoinnovation. [Online]. Available: https://www.oecd.org/env/consumption-innovation/43960830.pdf

[15] Kemp, R. (2011). Ten themes for eco-innovation policies in Europe. [Online]. Available: https://sapiens.revues.org/1169

[16] Levidow, L. (2016). Process eco-innovation: assessing meso-level eco-efficiency in industrial water-service systems. Journal of Cleaner Production, vol. 110, pp. 54-65. doi: 10.1016/j.jclepro.2014.12.086

[17] Ociepa-Kubicka, A., \& Pachura, P. (2017). Eco-innovations in the functioning of companies. Environmental Research, vol. 156, pp. 284-290. doi: 10.1016/j.envres.2017.02.027

[18] OECD (2005). Oslo Manual: Guidelines for Collecting and Interpreting Innovation Data. Paris: OECD.

[19] OECD (2010). Eco-innovation in Industry: Enabling Green Growth. [Online]. Available: http://dx.doi.org/10.1787/9789264077225-en

[20] Open Working Group proposal for Sustainable Development Goals. [Online]. Available: https://sustainabledevelopment.un.org/focussdgs.html 
[21] Pujari, D. (2006). Eco-innovation and new product development: understanding the influences on market performance. Technovation, vol. 26, no. 1, pp. 76-85. doi: 10.1016/j.technovation.2004.07.006

[22] Rennings, K. (2000). Redefining innovation - Eco-innovation research and the contribution from ecological economics. Ecological Economics, vol. 32, pp. 319-322. doi: 10.1016/S0921-8009(99)00112-3

[23] Rennings, K., Ziegler, A., \& Zwick T. (2003). Employment Changes in Environmentally Innovative Firms. [Online]. Available: ftp://ftp.zew.de/pub/zew-docs/dp/dp0146.pdf. doi: $10.2139 /$ ssrn. 329120

[24] Rio, P., Penasco, C., \& Romero-Jordan, D. (2106). What drives eco-innovators? A critical review of the empirical literature based on econometric methods. Journal of Cleaner Production, vol. 112, no. 4, pp. 2158-2170.

[25] Scientific and Innovation Activities of Ukraine (2016). Statistical Yearbook. Kyiv, State Statistics Service of Ukraine, $257 \mathrm{p}$.

[26] Schiederig, T., Tietze, F., \& Herstatt, C. (2012). Green innovation in technology and innovation management - an exploratory literature review. $R \& D$ Management, vol. 42, pp. 180-192. doi: 10.1111/j.1467-9310.2011.00672.x

[27] Skypalova, R., Kucerova, R., \& Blaskova, V. (2016). Development of the corporate social responsibility concept in small and medium-sized enterprises. Prague Economic Papers, vol. 25 , no. 3, pp. 287-303. doi: 10.18267/j.pep.558

[28] The Eco-Innovation Scoreboard and the Eco-innovation Index. [Online]. Available: http://ec.europa.eu/environment/ecoap/scoreboard_en

[29] Triguero, A., Moreno-Mondejar, L., \& Davia M.A. (2013). Drivers of different types of eco-innovation in European SMEs. Ecological economics, vol. 92, pp. 25-33. doi: 10.1016/j.ecolecon.2013.04.009

[30] Tsai, K.H., \& Liao, Y.C. (2017). Sustainability Strategy and Eco-Innovation: A moderation Model. Business Strategy and The Environment, vol. 26, no. 4, pp. 426-437. doi: $10.1002 /$ bse. 1926

[31] Ukraine (2013). Enterprise Surveys. [Online]. Available: http://www.enterprisesurveys.org/data/exploreeconomies/2013/ukraine

[32] Urbaniec, M. (2015). Towards Sustainable Development through Ecoinnovations: Drivers and Barriers in Poland, Economics and Sociology, vol. 8, no. 4, pp. 179-190.

[33] Xavier, A.F. et al (2017). Systematic literature review of eco-innovation models: Opportunities and recommendations for future research. Journal of Cleaner Production, vol. 149, pp. 1278-1302. doi: 10.1016/j.jclepro.2017.02.145 